\title{
KEMAMPUAN KETERAMPILAN DASAR MENGAJAR MAHASISWA CALON GURU IPA PROGRAM STUDI PENDIDIAN IPA
}

\author{
Indri Nurwahidah \\ Prodi Pendidikan IPA, Fakultas Sains dan Teknologi, Universitas Ivet, Semarang \\ e-mail: indrinur555@gmail.com
}

Abstrak

Penerapan keterampilan dasar mengajar sangat penting untuk dilakukan oleh guru agar penyampaikan materi pembelajaran dapat berjalan dengan lancar, efektif, efisien, dan profesional. Tujuan penelitian ini adalah untuk mengetahui kemampuan keterampilan dasar mengajar mahasiswa calon guru IPA pada mata kuliah microteaching. Jenis penelitian yang digunakan adalah penelitian kualitatif deskriptif untuk menggambarkan secara deskriptif kemampuan keterampilan dasar mengajar mahasiswa calon guru IPA pada mata kuliah microteaching. Berdasarkan hasil penelitian diketahui bahwa nila rata-rata keterampilan dasar mengajar pada latihan mengajar ke-1 dan ke-2 adalah 67 pada kategori baik. Dapat disimpulkan bahwa rata-rata kemampuan keterampilan dasar mengajar mahasiswa calon guru IPA pada program studi pendidikan IPA Universitas Ivet dalam kategori baik.

Kata kunci: calon guru, IPA, keterampilan dasar mengajar, microteaching.

\begin{abstract}
The application of basic teaching skills is very important to do by the teacher so that the delivery of learning materials can run smoothly, effectively, efficiently, and professionally. The aim of this research was to determine the ability of the basic teaching skills of prospective science teacher in microteaching class. This type of research is a descriptive qualitative to describe descriptively the ability of basic teaching skills prospective science teacher in microteaching class. Based on the results of this research could be define that the average value of basic teaching skills in the first or second teaching practise was 67 categorized as good. It can be concluded that the average ability of basic teaching skills of prospective science teacher students in the Ivet University IPA education study program is in the good category.
\end{abstract}

Keywords: prospective teacher, science, basic teaching skills, microteaching.

\section{Pendahuluan}

Kegiatan pembelajaran merupakan hal yang sangat penting dalam pendidikan yang melibatkan guru dan siswa [1] [2]. Dalam dunia pendidikan terutama di sekolah, interaksi antara guru dan siswa memiliki peranan yang utama untuk menentukan suatu pembelajaran dapat dikatakan berhasil [3]. Banyak jenis interaksi yang dilakukan oleh guru dan siswa, salah satunya interaksi di kelas yaitu dalam kegiatan proses pembelajaran. Guru bisa berhasil membimbing perserta didik untuk memperoleh pengetahuan dan kompetensi yang baik jika guru tersebut dapat melakukan perannya dengan baik. Sayangnya, tidak semua guru dapat melakukan hal itu. Untuk menjadi seorang guru tidak hanya dibutuhkan pengetahuan bidang keilmuannya saja tetapi banyak hal lain yang perlu dikuasai dengan baik. Menurut UU No 20 tahun 2005 tentang guru dan dosen, seorang guru harus memiliki empat kompetensi utama. Keempat kompetensi tersebut adalah pedagogik, profesional, kepribadian, dan sosial. Empat kompetensi tersebut harus diimplementasikan guru dalam mengajar di sekolah agar pembelajaran dapat berjalan dengan baik dan lancar [4] [5]. Antara satu kompetensi dengan kompetensi 
yang lainnya saling berkaitan. Dalam mempelajari dan memahami kompetensi tersebut sebelum menjadi guru, seseorang harus menempuh pendidikan formal jenjang perguruan tinggi pada program studi ilmu kependidikan.

Melalui pendidikan tinggi mahasiswa mempelajari bidang keilmuan sesuai dengan minatnya yang termasuk dalam kompetensi profesional. Namun tidak hanya itu saja, kompetensi pedagogik, kepribadian, dan sosial juga dipelajari melalui integrasi pada mata kuliah yang sesuai dalam kurikulum program studi. Terdapat beberapa perbedaan muatan materi pada mata kuliah kependidikan karena harus disesuaikan dengan bidang keilmuan masing-masing. Misalnya pada program studi pendidikan IPA, seorang mahasiswa calon guru harus lebih banyak memahami mengenai praktikum yang relevan dengan materi pembelajaran. Tidak hanya itu, seorang calon guru IPA selain harus memahami konsep materi dengan baik, menghubungkan materi dengan kehidupan sehari-hari siswa, menghubungkan konsep dengan percobaan atau praktikum tetapi juga harus mampu menyampaikan hal-hal tersebut kepada siswa dengan baik. Mahasiswa calon guru harus mempunyai keterampilan untuk menyampaikan kepada siswa agar ilmu yang dimiliki dapat tersamapaikan dan juga dapat diterima dengan baik oleh siswa. Hal ini berkaitan dengan kompetensi pedagogik. Agar calon guru IPA dapat melakukan hal tersebut dengan baik diperlukan metode atau cara yang tepat untuk digunakan dalam proses pembelajaran. Metode tersebut adalah keterampilan dasar mengajar yang disampaikan pada mata kuliah microteaching. Pada mata kuliah microteaching, mahasiswa calon guru IPA dituntut untuk dapat memahami dan menerapkan keterampilan dasar mengajar agar dapat mengajar dengan baik di depan kelas.

Menurut Shoffa [6] dan Helmiati [7] keterampilan dasar mengajar terdiri dari delapan yaitu: 1) keterampilan membuka dan menutup pelajaran; 2) keterampilan menjelaskan pelajaran; 3) keterampilan bertanya; 4) keterampilan mengadakan variasi; 5) keterampilan memberikan penguatan; 6) keterampilan mengelola kelas; 7) keterampilan mengajar kelompok kecil dan perseorangan; 8) keterampilan memimpin diskusi kelompok kecil. Delapan keterampilan dasar mengajar tersebut harus dikuasai dengan baik oleh calon guru IPA tanpa terkecuali. Antara satu keterampilan dengan keterampilan yang lain saling berkaitan dan saling mendukung satu sama lain. Misalnya keterampilan membuka pelajaran berkaitan dengan keterampilan mengelola kelas, karena ketika seorang guru akan memulai pelajaran harus mengkondisikan kelas terlebih dahulu agar siap menerima pelajaran. Dalam membuka pembelajaran guru memberikan motivasi agar siswa tertarik dengan materi yang akan disampaikan oleh guru sehingga kelas akan mudah untuk dikondisikan. Sebaliknya jika guru kurang terampil dalam membuka pembelajaran maka pengkondisian kelas juga akan sulit untuk dilakukan. Keterampilan dasar mengajar merupakan kemahiran seorang guru dalam menguraikan konsep-konsep materi pembelajaran di dalam kelas [8].

Penerapan keterampilan dasar mengajar sangat penting untuk dilakukan agar guru dalam menyampaikan materi pembelajaran dapat berjalan dengan lancar, efektif, efisien, dan profesional [9] [3] [10] [11] serta dapat meningkatkan kedisiplinan peserta didik [12]. Keterampilan dasar mengajar untuk calon guru perlu dilatih sejak awal karena persepsi siswa tentang keterampilan dasar mengajar seorang guru berpengaruh terhadap prestasi belajarnya [13]. Mahasiswa calon guru IPA diwajibkan untuk memahami delapan keterampilan dasar mengajar beserta indikator-indikator di dalamnya. Dengan demikian, diharapkan mahasiswa dapat berlatih mengaplikasikannya dalam praktik mengajar IPA. Sebelum mahasiswa calon guru IPA melakukan praktik mengajar di sekolah, ada beberapa tahapan yang harus dilalui salah satunya yaitu menempuh mata kuliah microteaching. Microteaching merupakan suatu metode yang dirancang untuk melatih keterampilan mengajar calon guru [7]. Menurut Shoffa [6], microteaching merupakan kegiatan latihan pembelajaran yang dilakukan pada situasi laboratoris. Semua mahasiswa ilmu pendidikan harus menempuh mata kuliah microteaching terlebih dahulu sebelum praktik langsung di sekolah melalui Praktik Pengalaman Lapangan (PPL) ataupun Pengenalan Lapangan Persekolahan (PLP). Menurut Aprilia \& Susilo [9] mahasiwa calon guru yang belum menguasai kompetensi dengan baik cenderung mengalami kesulitan bersosialisai di sekolah tempat melakukan praktik. Kendala yang sering dialami oleh mahasiswa yaitu dalam pemahaman dan penerapan kemapuan dasar-dasar mengajar [14]. Melalui microteaching, keterampilan dasar mengajar dapat dipelajari dan dilatih dengan baik [4] [14] [16]. 
Sebelum melakukan praktik mengajar skala kecil dalam mata kuliah microteaching, mahasiswa telah mendapatkan teori-teori tentang pembelajaran di dalam kelas melalui mata kuliah yang sebelumnya. Mahasiswa punya kreativitas masing-masing dalam menyerap ilmu dan mengimplementasikan keterampilan dasar mengajar yang dipahaminya melalui microteching. Tidak semua mahasiswa mampu mengimplementasikan dengan baik teori yang diterimnya dalam bentuk keterampilan dasar mengajar yang sesuai dengan materi pembelajaran. Banyak diantara mereka masih kesulitan menyesuaikan penggunaan keterampilan dasar mengajar yang sesuai dalam pembelajaran di dalam kelas. Perlu diketahui terlebih dahulu tingkat kemampuan mahasiswa calon guru agar dapat diberikan perlakukan yang tepat dalam meningkatkan kemampuan dasar mengajarnya. Tujuan dari penelitian ini adalah untuk mengetahui kemampuan keterampilan dasar mengajar mahasiswa calon guru IPA pada mata kuliah microteaching. Dengan diketahuinya kemampuan keterampilan dasar mengajar mahasiswa calon guru IPA maka dapat digunakan sebagai acuan dalam melakukan perbaikan dan peningkatan kemampuan keterampilan dasar mengajar.

\section{Metode Penelitian}

Jenis penelitian yang digunakan adalah penelitian kualitatif deskriptif untuk menggambarkan secara deskriptif kemampuan keterampilan dasar mengajar mahasiswa calon guru IPA pada mata kuliah microteaching. Pengambilan data dilakukan pada semester genap tahun akademik 2019-2020 pada mata kuliah microteaching Program Studi Pendidikan IPA Universitas Ivet. Penelitian ini melibatkan 9 mahasiswa semester VI. Target pada penelitian ini adalah kemampuan penggunaan keterampilan mengajar yang sesuai dalam pembelajaran di dalam kelas. Pengambilan data dilakukan dengan cara melakukan observasi langsung dan wawancara kepada mahasiwa tersebut. Observasi dilakukan dengan menggunakan lembar observasi sesuai dengan delapan keterampilan dasar mengajar yang terlihat pada Tabel 1 berikut.

Tabel 1. Indikator Penilaian Ketrampilan Dasar Mengajar

\begin{tabular}{|c|c|c|}
\hline No & Keterampilan dasar mengajar & Indikator \\
\hline 1. & $\begin{array}{l}\text { Keterampilan membuka dan menutup } \\
\text { pelajaran }\end{array}$ & $\begin{array}{ll}\text { - } & \text { Memfokuskan perhatian dan } \\
& \text { membangkitkan minat siswa } \\
\text { - } & \text { Menimbulkan motivasi } \\
\text { - } & \text { Memberi acuan } \\
\text { - } & \text { Mengaitkan pelajaran yang telah dipelajari } \\
& \text { dengan topik baru }\end{array}$ \\
\hline 2. & Keterampilan menjelaskan pelajaran & $\begin{array}{l}\text { - Menggunakan bahasa dengan baik dan } \\
\text { benar } \\
\text { - Menggunakan bahasa yang jelas baik kata- } \\
\text { kata maupun ungkapan } \\
\text { - Suara terdengar sampai ke seluruh bagian } \\
\text { kelas } \\
\text { - Volume suara bervariasi } \\
\text { - Menghindari kata-kata yang tidak perlu }\end{array}$ \\
\hline 3. & Keterampilan bertanya & $\begin{array}{l}\text { - Mengungkapkan pertanyaan dengan jelas } \\
\text { dan singkat } \\
\text { - } \text { Memusatkan ke arah jawaban yang diminta } \\
\text { - } \text { Memindahkan giliran menjawab } \\
\text { - } \text { Menyebarkan pertanyaan } \\
\text { - } \\
\text { - } \\
\text { Memberikan waktu berpikir } \\
\text { Meman tuntunan }\end{array}$ \\
\hline 4. & Keterampilan mengadakan variasi & $\begin{array}{l}\text { - Variasi dalam gaya mengajar guru } \\
\text { - } \quad \text { Variasi penggunaan media pembelajaran } \\
\text { - } \quad \text { Variasi pola interaksi dan aktivitas siswa }\end{array}$ \\
\hline 5. & Keterampilan memberikan penguatan & $\begin{array}{l}\text { - Penguatan berupa mimik dan gerakan badan } \\
\text { - Penguatan dengan cara mendekati }\end{array}$ \\
\hline
\end{tabular}


- Penguatan dengan sentuhan

- Penguatan dengan kegiatan yang menyenangkan

6. Keterampilan mengelola kelas

- Penguatan berupa simbol atau benda

- Penguatan berupa simbol atau benda

- Menunjukan sikap tanggap

- Membagi perhatian

- Memberikan petunjuk-petunjuk yang jelas

- Memberi teguran secara bijaksana

7. Keterampilan mengajar kelompok kecil dan perseorangan

- Keterampilan mengadakan pendekatan secara pribadi

- Keterampilan mengorganisasi

- Keterampilan membimbing dan memudahkan pelajaran

- Keterampilan merencanakan dan melaksanakan kegiatan belajar mengajar

8. Keterampilan memimpin diskusi - Memusatkan perhatian

kelompok kecil

- Memperjelas masalah urunan pendapat

- Menganalisis pandangan siswa

- Meningkatkan keterlibatan siswa

- Menyebarkan kesempatan berpartisipasi

- Menutup diskusi

Dari indikator pada masing-masing keterampilan mengajar tersebut kemudian dikategorikan sesuai dengan Tabel 2.

Tabel 2. Kategori Kemampuan Penggunaan Keterampilan Dasar Mengajar

\begin{tabular}{lcc}
\hline No & Nilai & Kategori \\
\hline 1 & $0-20$ & Sangat kurang \\
2 & $21-40$ & Kurang \\
3 & $41-60$ & Cukup \\
4 & $61-80$ & Baik \\
5 & $81-100$ & Sangat baik \\
\hline
\end{tabular}

\section{Hasil dan Pembahasan}

Penelitian dilakukan pada mata kuliah microteaching semester ganjil 2019-2020 terhadap mahasiswa semester VI program studi pendidikan IPA Universitas Ivet. Penelitian dilakukan dengan cara melakukan observasi langsung kepada mahasiswa selama dua kali latihan mengajar untuk masingmasing mahasiswa. Latihan pertama dilakukan setelah mahasiswa memahami tentang 8 keterampilan dasar mengajar beserta tata caranya. Setelah latihan yang pertama, kemudian dilakukan evaluasi pada masing-masing mahasiswa untuk mengetahui kekurangan dan kelebihan masing-masing mahasiswa calon guru IPA. Saran untuk perbaikan praktik mengajar tidak hanya disampaikan oleh dosen pengampu, tetapi masing-masing mahasiswa diminta untuk memberikan saran untuk yang lainnya. Hal ini dilakukan agar pada latihan ke-2 mahasiswa calon guru dapat lebih memaksimalkan latihannya dengan cara melakukan perbaikan melalui saran-saran yang telah disampaikan sebelumnya. Kemampuan dasar mengajar mahasiswa calon guru IPA dapat dilihat pada Tabel 3. 
Tabel 3. Kemampuan Dasar Mengajar Mahasiswa Calon Guru IPA

\begin{tabular}{|c|c|c|c|c|c|}
\hline \multirow[t]{2}{*}{ No } & \multirow[t]{2}{*}{ Keterampilan dasar mengajar } & \multicolumn{2}{|c|}{ Penilaian ke- } & \multirow[t]{2}{*}{ Rata-rata } & \multirow[t]{2}{*}{ Kategori } \\
\hline & & 1 & 2 & & \\
\hline 1. & $\begin{array}{l}\text { keterampilan membuka dan menutup } \\
\text { pelajaran }\end{array}$ & 66 & 70 & 68 & Baik \\
\hline 2. & keterampilan menjelaskan pelajaran & 68 & 71 & 69 & Baik \\
\hline 3. & keterampilan bertanya & 67 & 72 & 70 & Baik \\
\hline 4. & keterampilan mengadakan variasi & 63 & 67 & 65 & Baik \\
\hline 5. & keterampilan memberikan penguatan & 62 & 68 & 65 & Baik \\
\hline 6. & Keterampilan mengelola kelas & 65 & 69 & 67 & Baik \\
\hline 7. & $\begin{array}{l}\text { keterampilan mengajar kelompok } \\
\text { kecil dan perseorangan }\end{array}$ & 65 & 70 & 67 & Baik \\
\hline 8. & $\begin{array}{l}\text { keterampilan memimpin diskusi } \\
\text { kelompok kecil }\end{array}$ & 65 & 69 & 67 & Baik \\
\hline & Rata-rata & 65 & 70 & 67 & Baik \\
\hline
\end{tabular}

Berdasarkan Tabel 3. Terlihat bahwa nilai rata-rata keterampilan dasar mengajar pada latihan mengajar ke-1 dan ke-2 adalah 67 pada kategori baik. Hal ini senada dengan penelitian Frasetyana [15] dan Agustina [4]. Pada latihan ke-1, dari delapan keterampilan dasar mengajar diperoleh nilai ratarata yaitu 65 dalam kategori baik. Pada latihan yang ke-1 nilai terendah terletak pada kemampuan memberikan penguatan yaitu 62. Rata-rata mahasiswa calon guru IPA masih kesulitan dalam memberikan penguatan kepada siswa dengan indikator, 1) kemampuan memberikan penguatan berupa mimik dan gerakan badan; 2) kemampuan memberikan penguatan dengan cara mendekati; 3) kemampuan memebrikan penguatan dengan sentuhan; 4) kemampuan memeberikan penguatan dengan kegiatan yang menyenangkan; dan 5) kemampuan dalam memberikan penguatan berupa simbol atau benda. Berdasarkan hasil wawancara diperoleh informasi bahwa mahasiswa calon guru IPA mengalami kesulitan karena masih kesulitan dalam menentukan mimik dan gerakan badan yang tepat karena belum terbiasa berada di depan kelas sehingga masih merasa canggung dan belum bebas berekspresi. Mahasiswa calon guru IPA juga masih kurang percaya diri dalam mendekati maupun memberikan penguatan berupa sentuhan kepada siswa misalnya dengan cara menepuk bahu. Pada indikator memberikan penguatan dengan kegiatan yang menyenangkan serta penggunaan simbol sudah dapat dilakukan oleh beberapa mahasiswa meskipun belum maksimal. Kekurangan yang ada pada latihan mengajar yang pertama berhasil diperbaiki pada latihan yang ke-2. Hal ini dapat dilihat pada Tabel 3, terjadi peningkatan nilai pada seluruh keterampilan dasar mengajar.

Keterampilan dasar dengan nilai tertinggi pada latihan ke-1 yaitu pada kemampuan menjelaskan pelajaran. Dalam hal ini berarti mahasiswa calon guru IPA sudah bisa menggunakan bahasa dengan baik, benar dan jelas serta suara dapat terdengar sampai seluruh bagian kelas dengan volume suara yang bervariasi. Hal ini merupakan suatu keunggulan karena meskipun baru pertama kali melakukan praktik mengajar rata-rata mahasiswa sudah dapat melakukan kegiatan sesuai dengan indikator-indikator pada keterampilan menjelaskan dengan baik. Bahasa dan volume suara merupakan hal yang sangat penting dalam proses pembelajaran. Ketika bahasa yang digunakan kurang jelas, maka dapat menghambat siswa dalam menerima dan memahami materi yang telah disampaikan oleh guru. Begitu pula dengan volume dan variasi suara, jika volume suara kurang keras maka siswa yang duduk 
di belakang atau pada jarak yang jauh dari guru akan kesulitan mendengar penjelasan mengenai materi yang disampaikan tersebut. Dan jika guru tidak melakukan variasi suara ketika mengajar, siswa akan cepat bosan dan kurang bersemangat dalam belajar. Pada latihan ke-2 keterampilan menjelaskan oleh mahasiswa calon guru IPA juga meningkat.

Berdasarkan data tersebut dapat dikatakan ada kemauan serta usaha yang dilakukan oleh mahasiswa calon guru IPA untuk memperbaiki kekurangan-kekurangan yang ada pada latihan ke-1 sehingga keterampilan dasar mengajar ketika melakukan parktik mengajar pada latihan yang ke-2 meningkat dengan cukup baik. Pada latihan ke-2 nilai rata-rata paling tinggi yaitu pada keterampilan bertanya dengan nilai sebesar 72 dalam kategori baik. Nilai paling rendah terdapat pada kemampuan mengadakan variasi. Pada latihan mengajar yang ke-2 masih menunjukkan beberapa kekurangan mislnya dalam menentukan penggunaan media pembelajaran yang menarik dan sesuai dengan materi. Untuk mengetahui kemampuan mahasiswa calon guru IPA per indikator pada tiap indikator dapat dilihat pada Gambar 1.

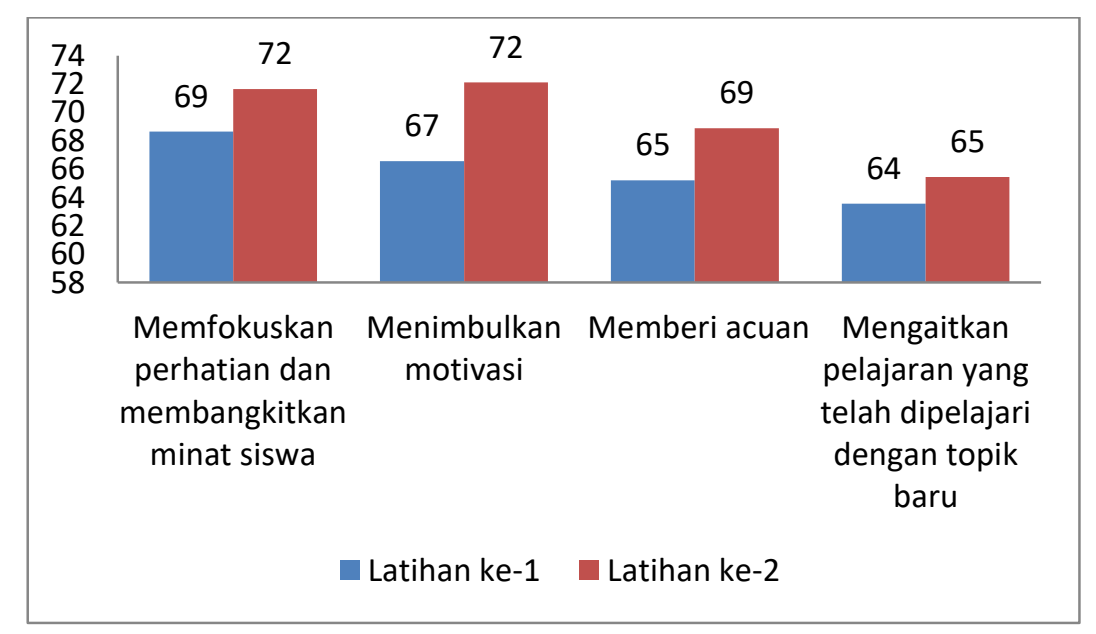

Gambar 1. Hasil Penilaian Indikator Keterampilan Membuka Dan Menutup Pelajaran

Berdasarkan Gambar 1, terlihat bahwa pada latihan yang ke-1 nilai paling baik yaitu pada indikator memfokuskan perhatian dan membangkitkan minat siswa dengan nilai 69, dan nilai tersebut meningkat dengan baik pada latihan ke-2. Nilai paling rendah yaitu pada indikator mengaitkan pelajaran yang telah dipelajari dengan topik baru dengan skor 64. Ternyata mahasiswa masih kesulitan dalam menghubungkan antara topik yang telah dipelajari dengan topik yang baru. Hal tersebut dikarenakan kurangnya pengetahuan dan latihan oleh para mahasiswa. Kekurangan tersebut masih terlihat pada latihan yang ke-2, karena pada latihan ke-2 indikator tersebut tetap menempati nilai terendah.

Selanjutnya pada keterampilan dasar mengajar yang kedua yaitu keterampilan menjelaskan pelajaran, nilai pada tiap indikator dapat dilihat pada Gambar 2. 


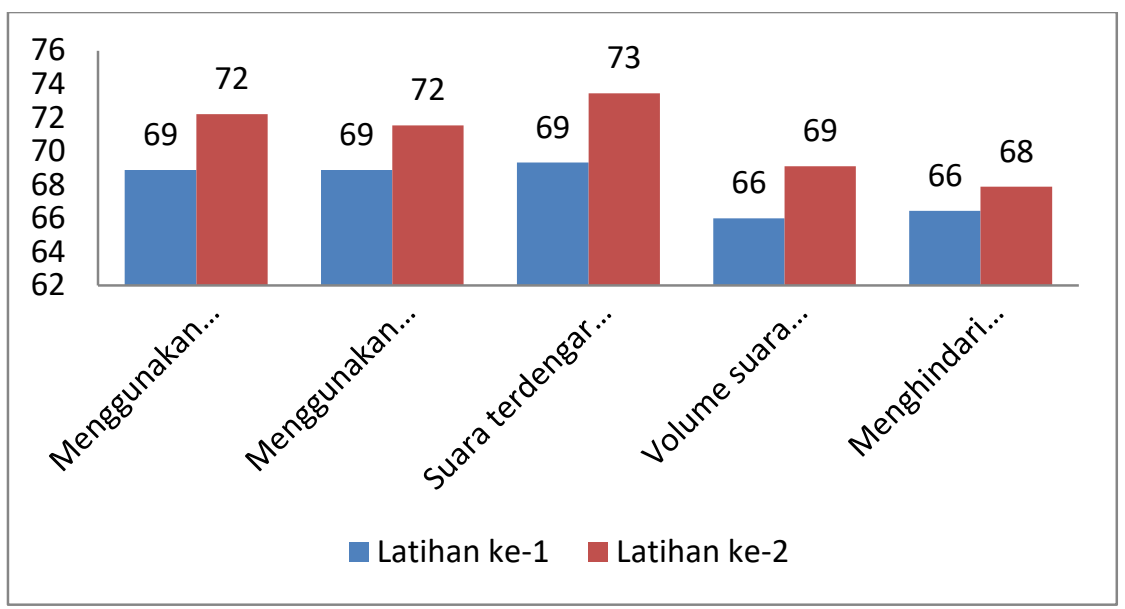

Gambar 2. Hasil Penilaian Indikator Keterampilan Menjelaskan Pelajaran

Berdasarkan Gambar 2, terlihat bahwa pada latihan mengajar ke-1 mahasiswa calon guru IPA belum bisa mengelola volume suara agar bervariasi sehingga tidak membuat siswa cepat jenuh dalam proses pembelajaran. Selain itu mahasiswa masih sering menggunakan kata-kata yang tidak perlu, hal ini terjadi karena mahasiswa calon guru canggung dan kurang percaya diri berdiri di depan kelas. Agar dapat memperbaiki dua indikator dengan nilai terendah tersebut dibutuhkan latihan yang cukup sehingga mahasiswa calon guru IPA lebih percaya diri di depan kelas dan tidak lagi canggung. Perbaikan terlihat pada latihan ke-2, hal ini menunjukkan bahwa mahasiswa calon guru IPA memiliki usaha yang baik dalam memperbaiki kekurangan tersebut. Meskipun demikian, pada latihan ke-2 indikator menghindari kata-kata yang tidak perlu masih menempati nilai terendah. Dibutuhkan latihan yang intensif agar mahasiswa dapat menghindari penggunaan kata-kata yang tidak diperlukan tersebut dalam pembelajaran.

Pada keterampilan dasar mengajar keterampilan bertanya menunjukkan nilai yang baik, ditunjukkan pada Gambar 3.

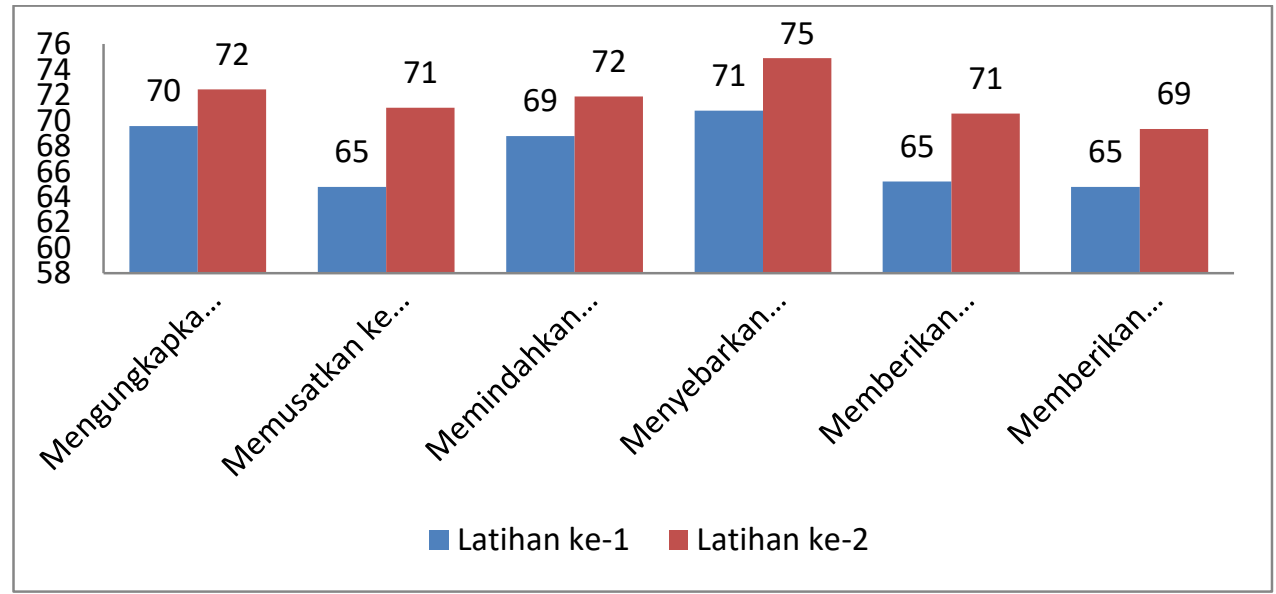

Gambar 3. Hasil Penilaian Indikator Keterampilan Bertanya

Diagram pada Gambar 3 menunjukkan kemampuan mahasiswa calon guru pada aspek keterampilan bertanya. Pada pertemuan ke-1 terdapat tiga indikator dalam keterampilan bertanya dengan nilai paling rendah, yaitu 1) kemampuan memusatkkan ke arah jawaban yang diminta; 2) memberikan waktu berpikir; dan 3) memberikan tuntunan. Ketiga indikator tersebut belum dapat 
dilakukan dengan baik oleh mahasiswa calon guru IPA karena mahasiswa belum bisa membuat alur atau tahapan yang jelas dalam menggiring siswa menuju jawaban yang benar sehingga ketika jawaban siswa keluar dari luar topik pembahasan, mahasiswa calon guru IPA masih kesulitan dalam mengarahkan kembali jawaban siswa tersebut menuju topik bahasan.

Kedua, mahasiswa calon guru IPA terlalu cepat dalam memberikan waktu setelah pertanyaan diberikan sehingga jeda waktu untuk mencari jawaban yang tepat terbilang masih kurang. Ketiga, mahasiswa calon guru IPA masih kesulitan dalam memberikan tuntunan dalam memberikan pertanyaan. Pertanyaan yang diberikan belum menggiring siswa untuk memperoleh informasi yang runtut terhadap materi yang sedang dipelajari. Hal ini terjadi karena mahasiswa kurang percaya diri sehingga seringkali lupa mengenai urutan penyampaian materi yang tepat. Kekurangan tersebut berhasil diperbaiki pada latihan yang ke-2, dapat terlihat dari kenaikan nilai pada tiga indikator tersebut. Selain keterampilan bertanya, mahasiswa juga harus mampu mengadakan variasi dalam pembelajaran agar siswa tidak jenuh. Hasil penilaian keterampilan mengadakan variasi dalam pembelajaran terlihat pada Gambar 4.

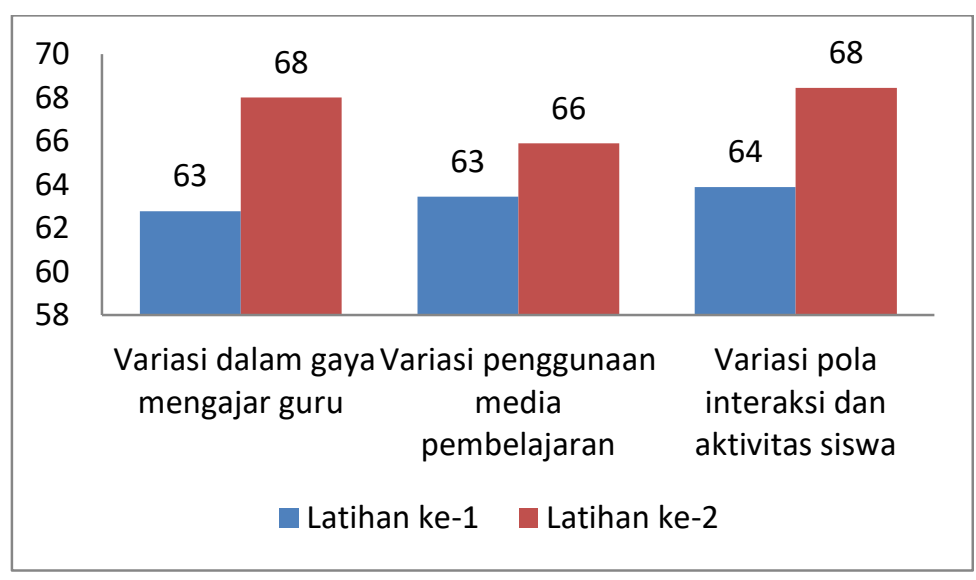

Gambar 4. Hasil Penilaian Indikator Keterampilan Mengadakan Variasi

Berdasarkan Gambar 4, pada latihan ke-1 rata-rata nilai pada tiap indikator sangat rendah. Hal ini menunjukkan bahwa kemampuan mahasiswa calon guru IPA dalam mengadakan variasi pada proses pembelajaran masih perlu diperbaiki melalui latihan. Setelah diberikan masukan-masukan untuk perbaikan, nilai pada tiap indikator meningkat pada latihan yang ke-2. Namun peningkatan tersebut belum maksimal dikarenakan nilainya masih lebih rendah dibanding dengan aspek keterampilan dasar mengajar yang lain. Untuk hasil penilaian indikator keterampilan memberikan penguatan dapat dilihat pada Gambar 5. 


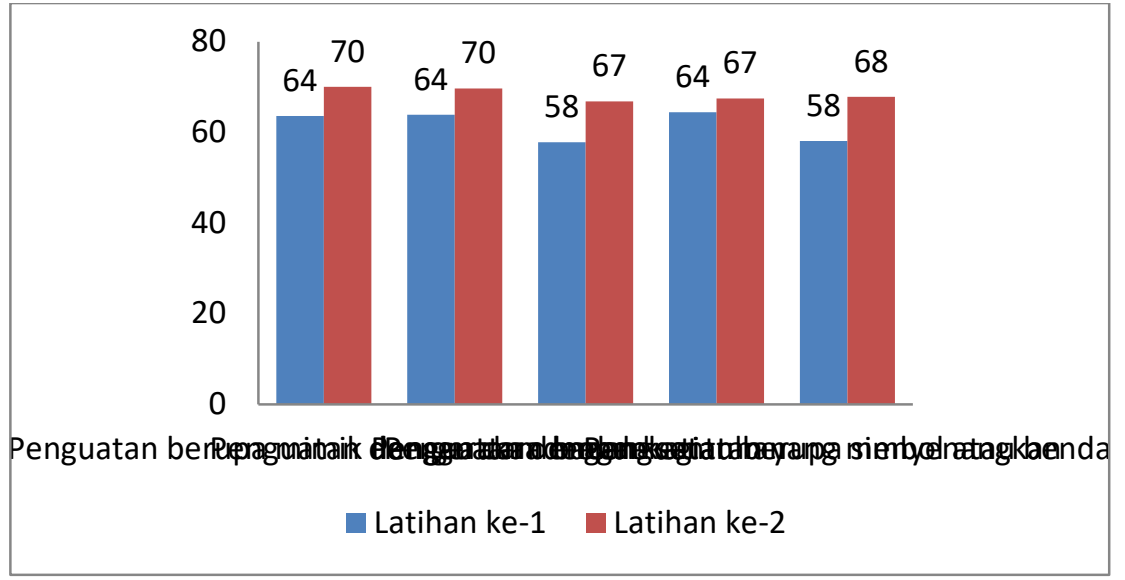

Gambar 5. Hasil Penilaian Indikator Keterampilan Memberikan Penguatan

Pada Gambar 5, ada dua indikator keterampilan memberikan penguatan dengan nilai yang kurang baik pada latihan ke-1. Bahkan nilai tersebut dibawah 60 dalam kategori cukup. Kedua indikator tersebut adalah keterampilan memberikan penguatan dengan sentuhan dan kemampuan memberikan penguatan dengan simbol atau benda. Hal ini terjadi karena mahasiswa calon guru IPA masih canggung kepada siswanya. Mereka belum memiliki kepercayaan diri dalam memberikan penguatan dengan menepuk bahu atau mengacungkan jempol. Tentu hal ini harus diperbaiki karena pemberian penguatan sangat penting dalam memberikan rasa percaya diri dan motivasi kepada siswa karena usahanya misalnya dalam menjawab pertanyaan dapat diapresiasi dengan baik oleh gurunya. Terlihat setelah latihan ke-2 nilai pada kedua indikator tersebut mengalami kenaikan. Keterampilan lain yang tak kalah penting yaitu keterampilan mengelola kelas. Karena tanpa kemampuan ini sepandai apapun guru, materi yang disampaikan tidak dapat diterima dengan baik jika disampaikan dalam kondisi kelas yang belum kondusif. Hasil penilaian keterampilan mengelola kelas dapat dilihat pada Gambar 6.

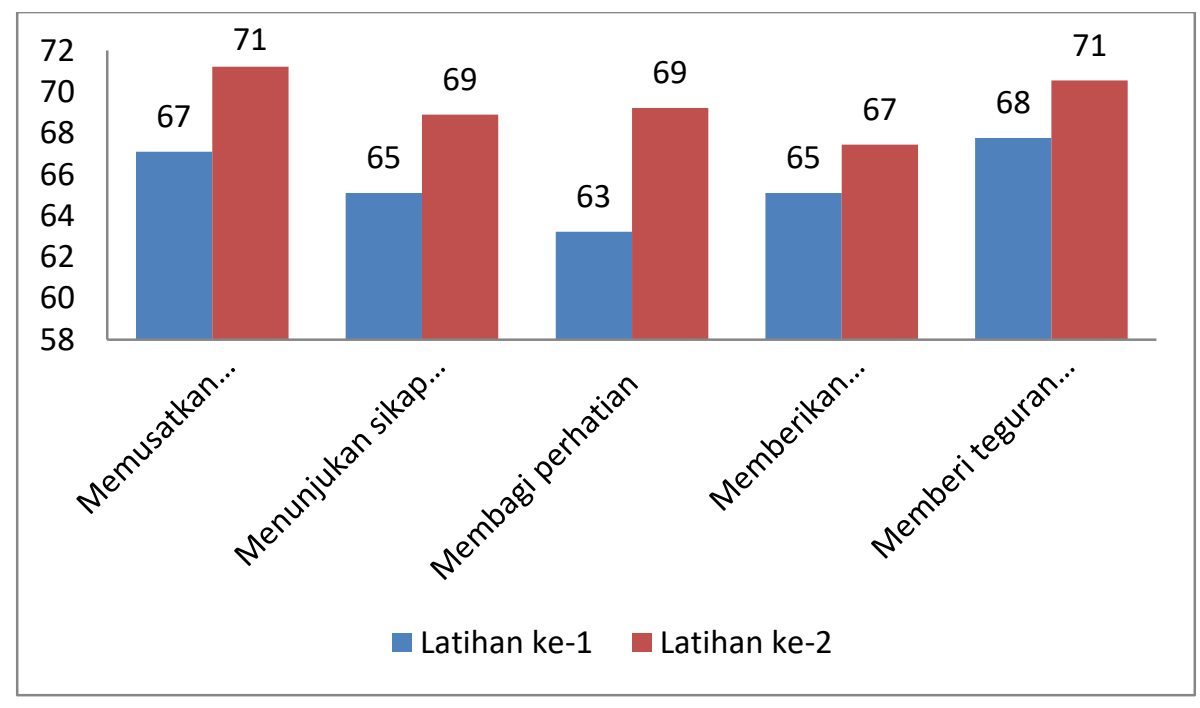

Gambar 6. Hasil Penilaian Indikator Keterampilan Mengelola Kelas

Sesuai dengan Gambar 6 terlihat bahwa nilai terendah yaitu pada indikator membagi perhatian. Mahasiswa calon guru IPA belum mampu membagi perhatian kepada seluruh siswa dengan adil. Salah satu tantangan guru dalam mengajar yaitu guru harus dapat memberikan perhatian kepada seluruh siswa tanpa ada yang merasa tidak diperhatikan. Maka dari itu apapun yang dilakukan siswa di dalam kelas, 
termasuk menjawab pertanyaan dari guru maupun mengajukan pertanyaan ketika proses pembelajaran perlu diberikan apresiasi dengan baik. Hal yang sama perlu diterapkan ketika mengajar kelompok kecil dan perseorangan. Hasil penilaian indikator keterampilan mengajar kelompok kecil dan perseorangan dapat dilihat pada Gambar 7.

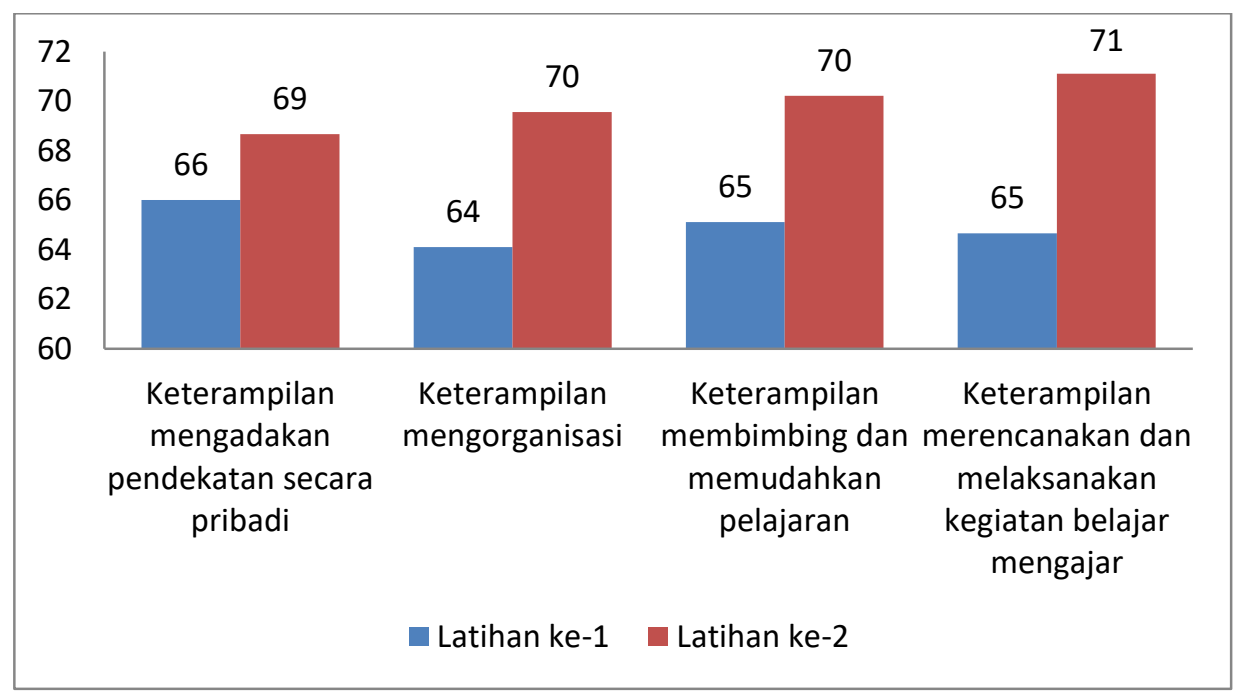

Gambar 7. Hasil Penilaian Indikator Keterampilan Mengajar Kelompok Kecil dan Perseorangan

Berdasarkan Gambar 7, kemampuan paling rendah yaitu pada indikator keterampilan mengorganisasi. Mahasiswa calon guru belum mampu mengorganisir kegiatan-kegiatan yang dilakukan siswa di kelas dengan baik. Selian itu kemampuan dalam menerapkan keterampilan membimbing serta melaksanakan kegiatan belajar mengajar juga tidak berbeda jauh. Mahasiswa belum terbiasa menghadapi siswa dan belum bisa melakukan improvisasi dengan baik ketika apa yang telah direncanakan dalam RPP ternyata tidak dapat dilakukan di kelas. Mahasiswa calon guru perlu lebih banyak latihan untuk menambah intensitas interkasi dengan siswa. Dengan semakin banyak latihan diharapkan keterampilan dalam mengorganisasi maupun melaksanakan kegiatan belajar mengajar semakin lebih baik. Hal ini terlihat pada latihan ke-2, bahwa nilai pada indikator tersebut meningkat dengan baik. Dan untuk hasil penilaian pada indikator keterampilan memimpin diskusi kelompok kecil danapt dilihat pada Gambar 8.

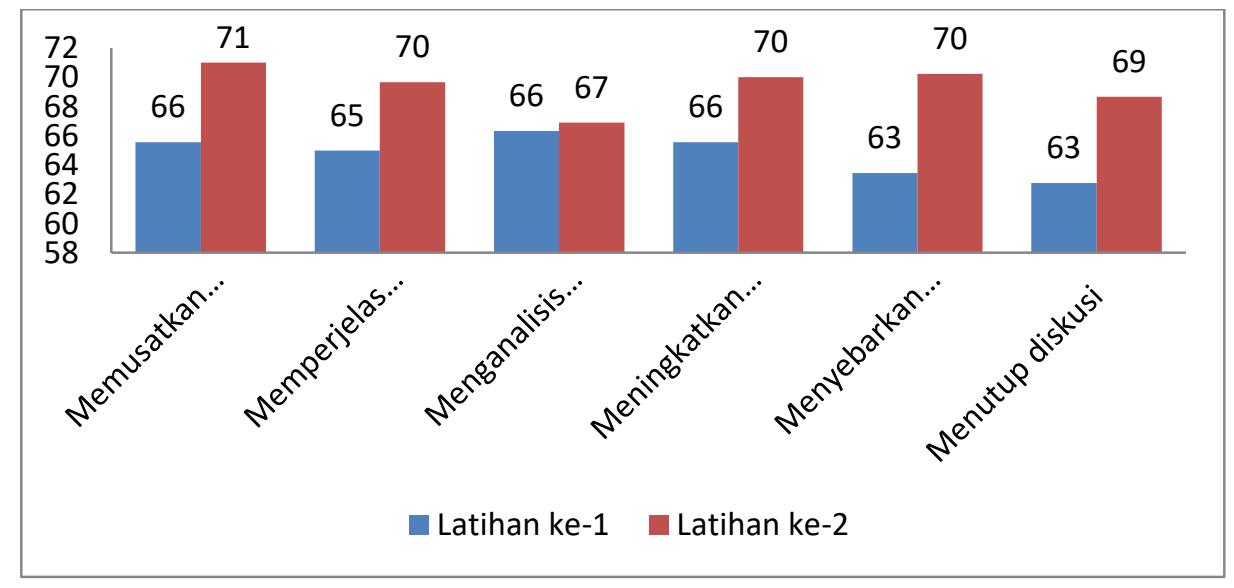

Gambar 8. Hasil Penilaian Indikator Keterampilan Memimpin Diskusi Kelompok Kecil 
Berdasrkan Gambar 8, kemampuan terendah terdapat pada keterampilan menyebarkan kesempatan berpasrtisipasi dan menutup diskusi. Hal ini ditunjukkan pada latihan mengajar ke-1, ketika melakukan microteaching mahasiswa calon guru IPA cenderung memberikan kesempatan menjawab pertanyaan hanya kepada siswa yang aktif saja. Hal ini tentu kurang memberikan kesempatan kepada siswa yang pendiam atau kurang aktif. Selain itu terdapat kekurangan dalam menutup diskusi, seringkali dalam menutup diskusi tidak disimpulkan terlebih dahulu hasil diskusi yang telah dilakukan. Namun kekurangan tersebut telah diperbaiki dengan baik oleh mahasiswa calon guru IPA pada latihan ke-2.

Secara umum keterampilan dasar mengajar mahasiswa calon guru IPA meningkat dari latihan mengajar ke-1 dan latihan ke-2, hal ini senada dengan penelitain yang dilakukan oleh Agustina [4], Luzyawti [17], dan Sutisnawati [18]. Sama halnya dengan penelitian yang dilakukan Utari [19] juga menunjukkan bahwa pengetahuan mahasiswa tentang keterampilan dasar mengajar dalam menghadapi PPLK pada kategori baik. Namun masih terdapat beberapa kekurangan karena pada latihan ke-2 masih terdapat nilai yang belum maksimal pada masing-masing indikator. Hal ini menunjukkan bahwa kemampuan keterampilan dasar mengajar mahasiswa calon guru IPA perlu ditingkatkan lagi. Menurut Supriyanto Supriyanto \& Sulistyaningrum, (2019) keterampilan dasar mengajar dapat ditingkatkan menggunakan model pembelajaran microteaching berbasis ekspreiental learing. Menurut Rauf [20] penggunaan video dalam pelaksaan microteaching dapat mempermudah pengamatan terhadap aktivitas mahasiswa calon guru dalam melakukan praktek mengajar. Selain itu menurut Lestari [21] dan Ifrianti [22] penerapan model pembelajaran lesson study dapat meningkatkan keterampilan dasar mengajar. Model tersebut bisa dijadikan alternatif pada penelitian selanjutnya untuk menindaklanjuti penelitian ini.

Keterampilan dasar mengajar sangat penting untuk diterapkan dalam proses pembelajaran. Kurangnya kemampuan keterampilan dasar mengajar pada guru dapat menyebabkan kurangnya minat belajar pada siswa serta kesulitan dalam memahami materi dengan baik [3].

\section{Kesimpulan}

Berdasarkan uraian hasil penelitian dan pembahasan dapat disimpulkan bahwa rata-rata kemampuan keterampilan dasar mengajar mahasiswa calon guru IPA program studi pendidikan IPA Universitas Ivet dalam kategori baik. Meskipun begitu masih terdapat beberapa kekurangan dalam penggunaan keterampilan dasar mengajar pada mata kuliah microteaching, hal tersebut dapat diperbaiki dengan cara memperbanyak latihan mengajar.

Saran terhadap penelitian selanjutnya, perlu dilakukan penelitian lebih lanjut untuk meningkatkan keterampilan dasar mengajar mahasiswa calon guru IPA program studi pendidikan IPA Universitas Ivet.

\section{Daftar Pustaka}

[1] H. Deswita, "Profil tingkat penguasaan keterampilan dasar mengajar mahasiswa pendidikan matematika Universitas Pasir Pengaraian," J. Gantang, vol. 2, no. 1, pp. 51-62, 2017.

[2] N. Ngazizah, D. Safitri, and A. S. Hadi, "Evaluasi keterampilan mengajar mahasiswa PGSD semester VI pada mata kuliah pembelajaran mikro tahun akademik 2018/2019," in URECOL, 2019, no. Bidang MIPA dan Kesehatan, pp. 315-320.

[3] A. A. Habibie and R. A. Firmansyah, "Analisis keterampilan dasar mengajar guru kimia yang mengikuti MGMP MIPA,” JEC (Journal Educ. Chem., vol. 1, no. 1, pp. 9-14, 2019.

[4] P. Agustina and A. Saputra, "Profil keterampilan dasar mengajar mahasiswa calon guru biologi pada matakuliah microteaching," J. Bioedukatika, vol. 5, no. 1, pp. 18-28, 2017.

[5] A. Sadikin and N. Hakim, "Buku ajar berbantuan model pembelajaran everyone ia a teacher here: upaya meningkatkan keterampilan dasar mengajar calon guru biologi," Assim. Indones. J. Biol. Educ., vol. 2, no. 2, pp. 47-51, 2019. 
[6] S. Shoffa, Keterampilan dasar mengajar microteaching, no. February. Surabaya: Mavendra Pers, 2017.

[7] Helmiati, Micro teaching. Yogyakarta: Aswaja Pressindo, 2013.

[8] R. Susanti, P. Setyosari, and Z. Abidin, "Persepsi mahasiswa teknologi pendidikan universitas negeri malang tentang Pentingnya keterampilan dasar mengajar terhadap kompetensi lulusan teknologi pendidikan," JKTP J. Kaji. Teknol. Pendidik., no. 2008, pp. 263-272, 2012.

[9] N. Aprilia and M. J. Susilo, "Pengembangan instrumen evaluasi pembelajaran microteaching berbasis perspekti keterampilan dasar mengajar," J. BIOEDUKATIKA, vol. 2, no. 2, pp. 9-13, 2014.

[10] Mansyur, "Keterampilan dasar mengajar dan penguasaan kompetensi guru (suatu proses pembelajaran micro)," el-Ghiroh (Jurnal Stud. Keislaman), vol. 12, no. 1, pp. 130-147, 2017.

[11] D. Alita, E. Enawaty, and H. A. Melati, "Analisis keterampilan dasar mengajar guru kimia SMA di Pontianak berdasarkan kurikulum 2013," J. Pendidik. dan Pembelajaran, vol. 3, no. 12, pp. $1-13,2014$.

[12] S. K. Elprida, I. W. Sujana, and L. A. Tirtayani, "Pengaruh keterampilan dasar mengajar guru terhadap perilaku disiplin pada anak usia dini kelompok B," J. Pendidik. Anak Usia Dini Undiksha, vol. 6, no. 1, pp. 11-20, 2018.

[13] I. A. Lestari, H. Amir, and S. Rohiat, "Hubungan persepsi siswa kelas X MIPA di SMA Negeri sekota Bengkulu tahun ajaran 2016/2017 tentang variasi gaya mengajar guru dengan hasil belajar kimia," ALOTROP J. Pendidik. dan Ilmu Kim., vol. 1, no. 2, pp. 113-116, 2017.

[14] Y. Supriyanto and H. Sulistyaningrum, "Meningkatkan keterampilan microteaching berbasis experiential learning melalui peran kelompok dan model," J. Pendidik. Ekon. Manaj. dan Keuang., vol. 3, no. 1, pp. 33-46, 2019.

[15] A. D. Frasetyana, I. Sujadi, and T. A. Kusmayadi, "Analisis keterampilan dasar mengajar mahasiswa pendidikan matematika dalam pembelajran mikro," J. Elektron. Pembelajaran Mat., vol. 3, no. 4, pp. 383-394, 2015.

[16] M. Ardi, "Pelaksanaan pembelajaran bagi mahasiswa program studi PPKn STKIP-PGRI Pontianak," J. Edukasi, vol. 1, no. 88, pp. 75-84, 2014.

[17] L. Luzyawati, "Profil tingkat penguasaan keterampilan dasar mengajar mahasiswa calon guru biologi," J. Pengajaran Mat. dan Ilmu Pengetah. Alam, vol. 20, no. 1, p. 88, 2015.

[18] A. Sutisnawati, "Analisis keterampilan dasar mengajar mahasiswa calon guru sekolah dasar," $J$. $M P D$, vol. 8, no. 1, pp. 15-24, 2017.

[19] M. Utari and I. G. Rani, "Tingkat pengetahuan mahasiswa program studi pendidikan Teknik Bangunan Jurusan Teknik Sipil FT UNP tentang kompetensi dasar mengajar dalam menghadapi PPLK," Cived, vol. 6, no. 3, 2019.

[20] A. Rauf, "Aplikasi video klip dengan rubrik penilaian terhadap peningkatan keterampilan proses pada pembelajaran micro teaching mahasiswa program studi biologi," J. Pendidik. dan Pembelajaran, vol. 1, no. 1, pp. 30-35, 2018.

[21] R. Lestari and N. Afifah, "Penerapan lesson study untuk meningkatkan kemampuan dasar mengajar mahasiswa Pendidikan Biologi Universitas Pasir Pengaraian," J. Pembelajaran Biol., vol. 1, no. 1, pp. 37-41, 2018.

[22] S. Ifrianti, "Membangun kompetensi pedagogik dan keterampilan dasar mengajar study," Terampil J. Pendidik. dan Pembelajaran Dasar, vol. 5, no. 1, p. 1, 2018. 